\title{
Investigation of Antifungal and Antioxidant Properties of Capparis ovata Methanolic Extracts
}

\author{
Capparis ovata Metanolik Ekstraktımn Antifungal ve Antioksidan Özelliklerinin Arastırlması
}

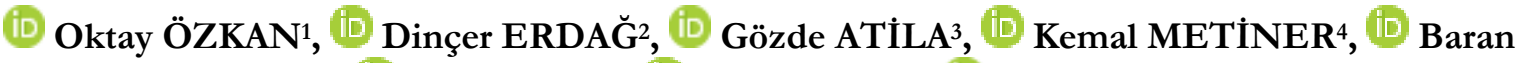 ÇELIKK ${ }^{5}$, Asim KART ${ }^{6 *}$, (i) Hamit USLU7 ${ }^{\text {, (D) Fatma Esin KIRIK }}{ }^{8}$}

\author{
${ }^{1}$ Niğde Ömer Halisdemir University, Faculty of Medicine, Department of Internal Medicine, Niğde \\ ${ }^{2}$ Kafkas University, Ataturk Health Vocational Higher School, Health Care Services Department, Kars \\ ${ }^{3}$ Kafkas University, Faculty of Veterinary Medicine, Department of Basic Sciences, Kars \\ ${ }^{4}$ Istanbul University, Faculty of Veterinary Medicine, Department of Preclinical Sciences, Istanbul \\ ${ }^{5}$ Istanbul University, Faculty of Veterinary Medicine, Department of Preclinical Sciences, Istanbul \\ 6* Burdur Mehmet Akif Ersoy University, Faculty of Veterinary Medicine, Department of Pharmacology and \\ Toxicology, Burdur \\ ${ }^{7}$ Kafkas University, Ataturk Health Vocational Higher School, Health Care Services Department, Kars \\ ${ }^{8}$ Niğde Ömer Halisdemir University, Faculty of Medicine, Department of Basic Medical Sciences, Niğde
}

\begin{abstract}
Caper plant belonging to the genus Capparis (family Capparaceae) is a plant used in traditional medicine to cure various illnesses since ancient times. Studies have shown significant medicinal properties of various Capparis species. This study was designed to examine in vitro antifungal and antioxidant activity of methanolic extracts of Capparis ovata buds. It was determined that $C$. ovata inhibited the NO radical in a dose-dependent manner and exhibited reducing power activity. According to the standard pyrocatechol graph, $1 \mathrm{mg}$ of $C$. ovata contains $19.64 \mu \mathrm{g}$ of phenolic equivalent of pyrocatechol. In vitro antifungal susceptibility testing of $C$. ovata methanolic extract against eight different fungal strains was determined by broth macrodilution method. According to MIC values of in vitro antifungal activity testing C. ovata has moderate antifungal activity. In conclusion, C. ovata was found to have a significant antifungal and antioxidant potential. Hence, this plant could have the potential to be used against fungal and oxidative stress related many disease conditions.
\end{abstract}

Keywords: Capparis ovata, Antifungal, Antioxidant, In vitro

Öz: Capparis genusuna (Capparaceae familyası) bağlı kapari bitkisi eski çağlardan beri geleneksel tıpta çeşitli hastalıkların tedavisinde kullanılmaktadır. Çeşitli Capparis türlerinin önemli tıbbi etkilerini ortaya çıkaran çalışmalar bulunmaktadır. Bu çalş̧mada C.ovata tomurcukları metanol ekstraktının in vitro antioksidan ve antifungal aktivitesi çalşsılmıştır. Capparis ovata'nn doza bağımlı olarak NO radikallerini inhibe ettiği ve indirgeyici güç aktivitesi gösterdiği tespit edilmiştir. Standart pirokatekol çizelgesine göre $1 \mathrm{mg}$ C. ovata 19,64 $\mu \mathrm{g}$ pirokatekole eş fenolik bileşik içermektedir. Capparis ovata metanol ekstraktı broth makrodilüsyon metodu ile sekiz farklı fungus suşuna karşı antifungal etkisi test edilmiştir. İn vitro antifungal aktivite testi MIC verilerine göre C. ovata llımlı antifungal etkiye sahiptir. Sonuç olarak C. ovata önemli derecede antifungal ve antioksidan potansiyele sahip bulunmuştur. Bu nedenle, bu bitki, mantar ve oksidatif stresle ilişkili birçok hastalık durumlarına karşı kullanıılma potansiyeline sahip olabilir.

\begin{tabular}{ll}
\hline Anahtar Kelimeler: Capparis ovata, Antifungal, Antioksidant, In vitro \\
\hline *Corresponding author : Asım KART & e-mail : akart@mehmetakif.edu.tr \\
Geliş tarihi / Received : 14.09 .2018 & Kabul tarihi / Accepted: 07.11.2018 \\
\hline
\end{tabular}

\section{Introduction}

The caper plant is locally called with different names as bubu, gebere, gabar, kapari, keper and kebere in Turkey. It is generally consumed as pickles due to economical and nutritional 
properties (Duman and Ozcan, 2014; Belviranle et al., 2016). This plant belongs to the family of Capparaceae and to the genus Capparis with 250 and 400 species. They are grown generally in tropical and subtropical regions but some also are in temperate regions in the Mediterranean including Turkey (Lansky et al., 2013). Capparis ovata have wide natural distribution, and it is cultivated in large parts of Turkey (Arslan et al., 2010; Haciseferogullar1 et al., 2011).

Different parts of capper plant have been used since ancient times for cosmetic, nutritional and medicinal purposes. In traditional medicine Capparis species were used to treat some disorders including rheumatic diseases, stomach problems, headache and toothache (Lansky et al., 2013; Tlili et al., 2011). Caper plant has different pharmacological activities and its various parts are used for pharmaceutical purposes (Arslan et al., 2010; Kondawar et al., 2011). The Capparaceae family generally contains glucosinolates, alkaloids and flavonoids, but the phytochemical composition of the contents obtained from different plant parts varies (Arslan et al., 2010; Tlili et al., 2011). A number of studies have shown that capparis species have significant immunostimulant, antitumoral, antidiabetic, antisclerosis, antimicrobial, antioxidative, antiinflammatory, immunomodulatory and antiviral activities. However, additional studies are needed to validate the use of Capparis species in medical treatment (Tlili et al., 2011; Zia-Ul-Hag et al., 2011; Mishra et al., 2007).

Studies indicate that the incidence and prevalence of some mycoses remains to be a public health challenge. Increased use of antifungal drugs has led to the resistance problems in today's world. In addition, due to increased number of multidrugresistant fungal strains and limited number of antifungal agents, it is necessary to discover new antifungals from natural products (Aqil et al., 2010).

Some medicinal plants possess potentially great antioxidant activity. Antioxidants are capable of preventing or protecting from the oxidative stress in cells. Hence, they have beneficial effects in the treatment of many diseases. Medicinal plants are a good source of natural antioxidants, which are alternative ways to use of synthetic antioxidants. They are also very good candidate for side effect free alternatives in comparison to synthetic antioxidants to be used in food industry and in preventive medicine (Ali et al., 2008; Krishnaiah et al., 2011).

Therefore, it is aimed to investigate the antioxidant and antifungal activities of $C$. ovata species in this study.

\section{Materials and Methods}

\section{Preparation of Plant Material and Extracts}

The buds of C. ovata were obtained from a local herbal shop in Kayseri Province (Gül Gıda ve Tarım Ürünleri) Turkey. Methanolic extracts of the buds were prepared according to the method described by Özkan et al. (2013) were stored at $25^{\circ} \mathrm{C}$ until used in the experiments.

\section{Antifungal Activity Testing}

\section{Test Microorganisms:}

The antifungal activities of $C$. ovata methanolic extracts were evaluated against different types of standard fungal strains including yeasts and filamtous fungi. Candida albicans (ATCC 90028), Candida parapsilosis (ATCC22019), Candida krusei (ATCC 6258), Malassezia pachydermatis yeast strains and Microsporum canis, Microsporum gypseum, Microsporum nanum and Trichophyton mentagrophytes filamentous fungi strains were used as test microorganisms and provided from the culture collection of Istanbul University Faculty of Veterinary Medicine Department of Microbiology.

\section{In Vitro Antifungal Susceptibility Testing:}

Reference methods were used according to the guidelines of the Clinical and Laboratory Standards Institute (CLSI) for in vitro antifungal 
susceptibility testing. Broth macrodilution assay was performed for determination of minimum inhibitory concentration (MIC) values of the methanolic extract of $C$. ovata buds using the guidelines CLSI M27-A3 for yeasts and CLSI M38-A2 for filamentous fungi (CLSI, 2008a; CLSI, 2008b). Broth macrodilution assay was also performed for Amphotericin B as a reference antifungal agent.

\section{Antioxidant Activity Testing}

\section{NO Radical Scavenging Activity}

Nitric oxide (NO) radical scavenging activity of C. ovata extract was measured according to the methods of Badami et al. (2003) and Kumar et al. (2005) with slight modification. The reaction is based on production of $\mathrm{NO}$ by sodium nitroprusside at physiological $\mathrm{pH}$. Nitric oxide interacts with oxygen to generate nitrite. Nitrite ions form a colored product by Greiss reaction, which is read at $548 \mathrm{~nm}$ to determine the NO level (Green et al., 1982).

\section{Reducing Power Capacity}

The reducing power of $C$. ovata extract was measured by the method of Oyaizu (1986).

\section{Determination of Total Phenolic Compounds}

Total soluble phenolic content of $C$. ovata extract was measured using Folin-Ciocalteu reagent according to the method of Slinkard and Singleton (1977).

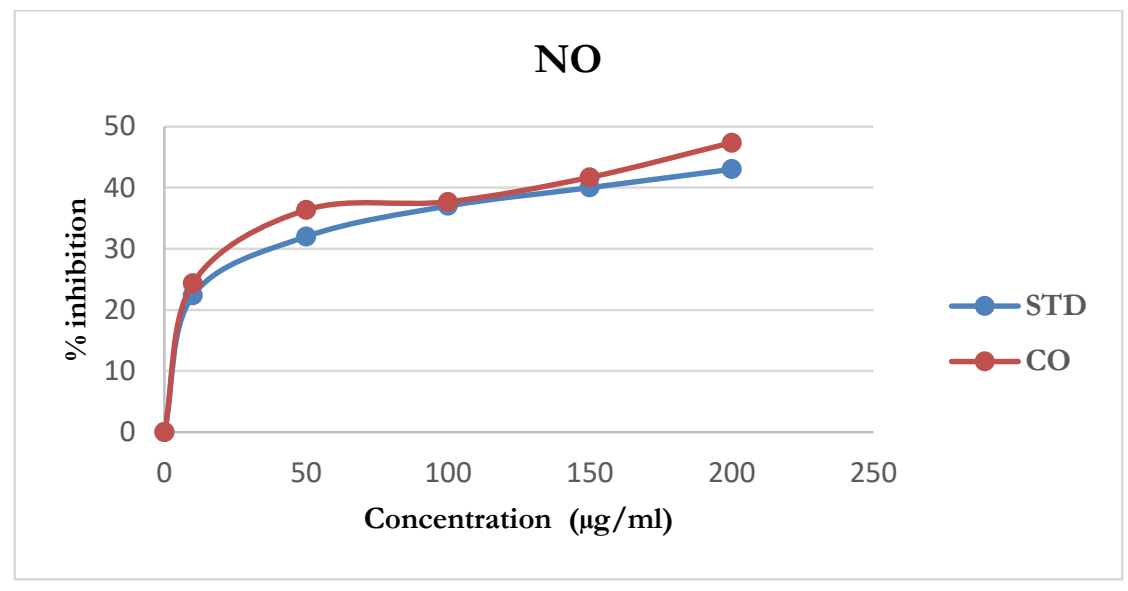

Figure 1. Inhibition of nitric oxide (NO) radicals by Capparis ovata and Rutin standard. 


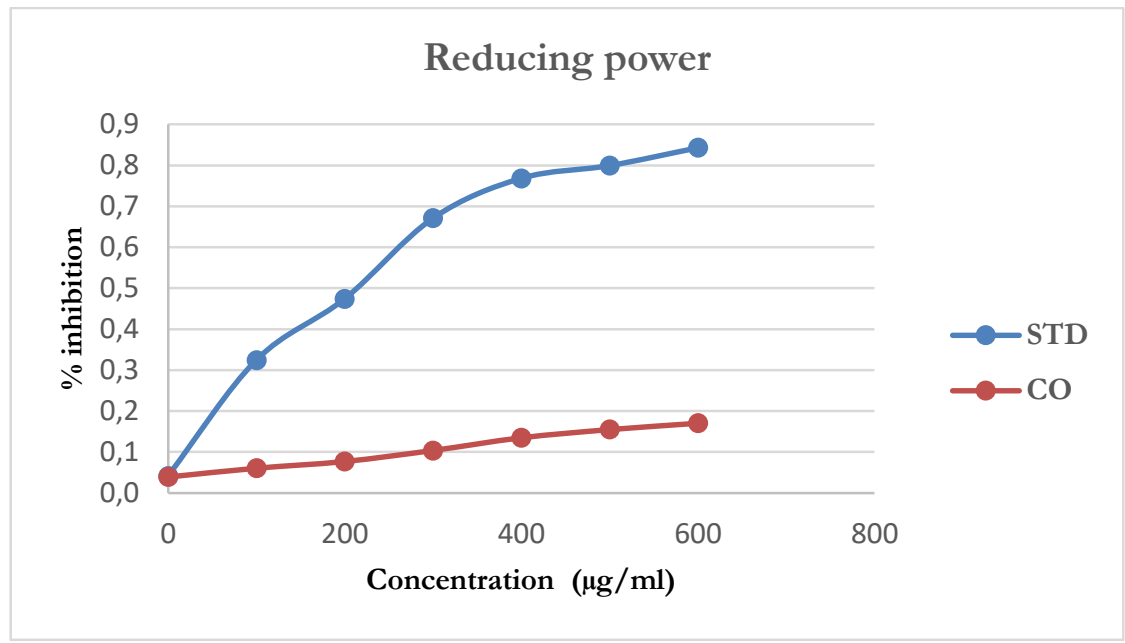

Figure 2. Reducing power of Capparis ovata and butylated hydroxyl toluene (BHT).

\section{Results}

The C. ovata methanolic extract at different amounts was compared with Rutin standard for NO radical scavenging activity (Figure 1).

Figure 2 illustrates the reducing power capacity of C. ovata extract in comparison to butylated hydroxyl toluene (BHT). The reducing power of C. ovata methanol extract increased with the increasing amounts of sample.

The absorbance value of $1 \mathrm{mg}$ of $C$. ovata extract was determined to be 0.031 at $760 \mathrm{~nm}$. It was found that $1 \mathrm{mg}$ of C. ovata contains $19.64 \mu \mathrm{g}$ of phenolic equivalent of pyrocatechol.

The results of broth macrodilution assay for antifungal susceptibility testing of $C$. ovata methanolic extract and the reference antifungal drug amphotericin B against fungal test strains are shown in Table 1. All of the tested fungal strains were sensitive to $C$. ovata methanolic extract. Candida krusei ATCC22019, Candida parapsilosis ATCC 6258 and Microsporum nanum strains were more sensitive to $C$. ovata. However, MIC values of $C$. ovata extracts against tested fungal strains were significantly higher than amphotericin B.

Table 1: In vitro antifungal susceptibility of Capparis ovata methanolic extract and amphotericin B against fungal test strains.

\begin{tabular}{lcc}
\hline \multicolumn{1}{c}{ Fungal Test Strains } & \multicolumn{2}{c}{ MIC values $\mathbf{~ m g / m l )}$} \\
\cline { 2 - 3 } & $\begin{array}{c}\text { Capparis ovata methanolic } \\
\text { extract } \mathbf{( m g / m l )}\end{array}$ & Amphotericin B (mg/ml) \\
\hline Candida albicans ATCC 90028 & 200 & 0.00024 \\
\hline Candida krusei ATCC22019 & 100 & 0.00195 \\
\hline Candida parapsilosis ATCC 6258 & 100 & 0.00195 \\
\hline Malassezia pachydermatis & 200 & 0.00024 \\
\hline Microsporum canis & 200 & 0.00024 \\
\hline Microsporum gypseum & 200 & 0.00024 \\
\hline Microsporum nanum & 100 & 0.00195 \\
\hline Trichophyton mentagrophytes & 200 & 0.00024 \\
\hline
\end{tabular}




\section{Discussion}

Previous studies indicate that the antioxidant activity of the C. ovata and other capparis species have high anti-oxidant activity (El-Ghorab et al., 2007; Naziroğlu et al., 2011; Unver et al., 2009; Duman et al., 2013; Naziroğlu et al., 2013). In this study, the results of radical scavenging activity of the C. ovata extract and the reducing power and phenolic compound content indicates that this plant is a potential antioxidant. Our results are similar to previous works studying other Capparis species. Zia-Ul-Haq et al. (2011) reported that $C$. decidua extracts have prominently high levels of phenolic compounds and showed potent antioxidant activity and reduced different types of radicals. El-Ghorab et al. (2007) showed that the methanolic extract of Capparis spinosa has a strong antioxidant activity. The ethyl acetate and aqueous extract of C. spinosa was reported to have DPPH scavenging activities (Yang et al., 2010).

Due to these properties, C. ovata has the potential to be used as a natural antioxidant source in both pharmaceutical and food industry.

Several studies indicate that many Capparis species have the antifungal activities against several fungal pathogens (Naziroğlu et al., 2011; Aslam $e t$ al. 2010; Sharma et al., 2009; Keymanesh et al., 2009; Malabadi et al., 2007; Buwa et al., 2006; Anywar et al., 2014; Rathee et al., 2013). However, there is lack of studies about antifungal activity of the species $C$. ovata. There are the reports that other Capparis species have antifungal activity. Capparis spinosa was assayed for antifungal activity toward the phytopathogenic fungi Valsa vali by Lam and Tzi-Bun Ng (2009). According to these results of research C. spinosa inhibited the reproduction of this fungus. Aslam et al. (2010) have tested the Capparis decidua against different fungus strains. In their study, they found that this herb is effective against to Rhizoctonia solani.

According to in vitro antifungal susceptibility testing results of this study, C. ovata has moderate antifungal activity.

In conclusion, this study indicates that $C$. ovata has an antioxidant and antifungal effect and is worth considering in therapeutic formulations to cure several diseases. However further studies are recommended to verify the role of this plant in herbal medicine for discovering new natural bioactive pharmaceuticals.

\section{References}

Ali, S. S., Kasoju, N., Luthra, A., Singh, A., Sharanabasava, H., Sahu, A., Bora, U., 2008. Indian medicinal herbs as sources of antioxidants. Food Research International 41(1), 1-15.

Anywar, G., Oryem-Origa, H., KamatenesiMugisha, M., 2014. Antibacterial and antifungal properties of some wild nutraceutical plant species from Nebbi district, Uganda. British Journal of Pharmaceutical Research 4(14), 17531761.

Aqil, F., Zahin, M., Ahmad, I., Owais, M., Khan, M. S. A., Bansal, S. S., Farooq, S., 2010. Antifungal activity of medicinal plant extracts and phytocompounds: A review. In Combating Fungal Infections.Springer, Berlin, Heidelberg. 449-484.

Arslan, R., Bektas, N., Ozturk, Y., 2010. Antinociceptive activity of methanol extract of fruits of Capparis ovata in mice. Journal of Ethnopharmacology 131(1), 28-32.

Aslam, A. Q. S. A., Naz, F., Arshad, M., Qureshi, R., Rauf, C.A., 2010. In vitro antifungal activity of selected medicinal plant diffusates against Alternaria solani, Rhizoctonia solani and Macrophomina phaseolina. Pakistan Journal of Botany 42(4), 2911-2919.

Badami, S., Gupta, M.K., Suresh, B., 2003. Antioxidant activity of the ethanolic extract of Striga orobanchioides. Journal of Ethnopharmacology 85,227-30.

Belviranlı, B., Özcan, M. M., Özcan, M.M., 2016. Chemical and microbiological properties of 
pickling of caper (Capparis ovata Desf. var. canescens) fruits. Journal of Agroalimentary Processes and Technologies 22(2), 95-101.

Buwa, L. V., Van Staden, J., 2006. Antibacterial and antifungal activity of traditional medicinal plants used against venereal diseases in South Africa. Journal of Ethnopharmacology 103(1), 139-142.

CLSI, 2008a. Reference method for broth dilution antifungal susceptibility testing of filamentous fungi; approved standard CLSI document M38-A2. Clinical and Laboratory Standards Institute, Wayne, PA, USA.

CLSI, 2008b. Reference method for broth dilution antifungal susceptibility testing of yeasts; Approved. Standard, Third Edition. CLSI document M27-A3. Clinical and Laboratory Standards Institute, Wayne, PA, USA.

Duman, E., Özcan, M.M., 2014. Physicochemical properties of seeds of Capparis species growing wild in Turkey. Environmental Monitoring and Assessment 186(4), 2393-2398.

Duman, H., Canatan, D., Alanoglu, G., Sutcu, R., Nayir, T., 2013. The antioxidant effects of Capparis ovata and deferasirox in patients with thalassemia major. Journal of Blood Disorders \& Transfusion 4(3), 3.

E1-Ghorab, A., Shibamoto, T., Özcan M.M., 2007. Chemical composition and antioxidant activities of buds and leaves of capers (Capparis ovata Desf. var. canescens) cultivated in Turkey. Journal of Essential Oil Research 19(1), 72-77.

E1-Ghorab, A., Shibamoto, T., Özcan, M.M., 2007. Chemical composition and antioxidant activities of buds and leaves of capers (Capparis ovata Desf. var. canescens) Cultivated in Turkey. Journal of Essential Oil Research 19, 72-77.
Green L.C., Wagner D.A., Glogowski J., Skipper P.L., Wishnok J.S., Tannenbaum S.R., 1982. Analysis of nitrate, nitrite, and [15N] nitrate in biological fluids, Anals of Biochemistry 126,131-8.

Haciseferoğulları, H., Özcan, M. M., Duman, E., 2011. Biochemical and technological properties of seeds and oils of Capparis spinosa and Capparis ovata plants growing wild in Turkey. Journal of Food Processing and Technology 2(6), 1000129.

Keymanesh, K., Hamedi, J., Moradi, S., Mohammadipanah, F., Sardari, S. 2009. Antibacterial, antifungal and toxicity of rare Iranian plants. International Journal of Pharmacology 5, 82-85.

Kondawar, M.S., Kamble, K.G., Khandare, M.M., Maharsh1, K.H., Awale, V.B., 2011. Evaluation of the locomotor and diuretic activities of ethanolic extract of leaves of Capparis divaricata lam. (capparidaceae). International Journal of Pharmacy and Pharmaceutical Sciences 3(4), 265-267.

Krishnaiah, D., Sarbatly, R., Nithyanandam, R., 2011. A review of the antioxidant potential of medicinal plant species. Food and Bioproducts Processing 89(3), 217-233.

Kumar, R.S., Sivakumar, T., Sunderam, R.S., Gupta, M., Mazumdar, U.K., Gomathi, P., Rajeshwar, Y., Saravanan, S., Kumar, M.S., Murugesh, K., Kumar, K.A., 2005. Antioxidant and antimicrobial activities of Baubinia racemosa $\mathrm{L}$. stem bark. Brazilian Journal of Medical and Biological Research 38,1015-24.

Lam, S.K., Ng, T.B., 2009. A protein with antiproliferative, antifungal and HIV-1 reverse transcriptase inhibitory activities from caper (Capparis spinosa) seeds. Phytomedicine 16(5), 444450. 
Lansky, E. P., Paavilainen, H. M., Lansky, S., 2013. Caper: the genus Capparis. CRC Press. Taylor \& Francis Group, Newyork, 345s.

Malabadi, R. B., Vijay Kumar, S., 2007. Assessment of antifungal activity of some medicinal plants. International Journal of Pharmacology 3(6), 499-504.

Mishra, S.N., Tomar, P.C., Lakra, N., 2007. Medicinal and food value of Capparis a hersh terrain plant. Indian Journal of Traditional Knowledge 6(1), 230-238.

Nazıroğl1, M., 2011. Capparis ovata modulates ovariectomize induced-oxidative toxicity in brain, kidney and liver of aged mice. Cell Membranes and Free Radical Research 3(2), 186-193.

Nazıroğlu, M., Akay, M. B., Çelik, Ö., Yıldırım, M. İ., Balcı, E., Yürekli, V.A., 2013. Capparis ovata modulates brain oxidative toxicity and epileptic seizures in pentylentetrazol-induced epileptic rats. Neurochemical Research 38(4), 780-788.

Oyaizu, M., 1986. Studies of products browning reaction: antioxidative activity of products of browning reaction prepared from glucosamine. Japanese Journal of Nutrition 44,307-15.

\section{Özkan, O., Gül S., Kart, A., Çiçek, B.A., Kılıç,} K., 2013. In vitro antimutagenicity of allium tuncelianum ethanol extract against induction of chromosome aberration by mutagenic agent mitomycine C. Kafkas Universitesi Veteriner Fakültesi Dergisi 19 (2), 259-262.

Rathee, S., Rathee, P., Rathee, D., Rathee, D., 2013. Antimicrobial activity of oleiyl glucoside isolated from the traditional medicinal plant, Capparis decidua. The Natural Products Journal 3(1), 52-59.
Sharma, B., Kumar, P., 2009. In vitro antifungal potency of some plant extracts against Fusarium oxysporum. International Journal of Green Pharmacy 3(1), 63.

Slinkard, K., Singleton, V.L., 1977. Total phenol analysis: automation and comparison with manual methods. The American Journal of Enology and Viticulture 28,49-55.

Tlili, N., Elfalleh, W., Saadaoui, E., Khaldi, A., Triki, S., Nasri, N., 2011. The caper (Capparis L.): Ethnopharmacology, phytochemical and pharmacological properties. Fitoterapia 82(2), 93-101.

Unver, A., Arslan, D., Ozcan, M. M., Akbulut, M., 2009. Phenolic content and antioxidant activity of some spices. World Applied Sciences Journal 6(3), 373-377.

Yang, T., Wang, C., Liu, H., Chou, G., Cheng, X., Wang, Z., 2010. A new antioxidant compound from Capparis spinosa. Journal Pharmaceutical Biology 48, (5). 589-594.

Zia-Ul-Haq, M., Ćavar, S., Qayum, M., Imran, I., Feo, V.D., 2011. Compositional Studies: Antioxidant and Antidiabetic Activities of Capparis decidua (Forsk.) Edgew. International Journal of Molecular Sciences 12, 8846-8861.

Zia-Ul-Haq, M., Ćavar, S., Qayum, M., Imran, I., Feo, W., 2011. Compositional studies: Antioxidant and antidiabetic activities of Capparis decidua (Forsk.) Edgew. International Journal of Molecular Sciences 12(12), 8846-8861. 